\title{
IMPLEMENTASI E-CRM DALAM JARINGAN USAHA RETAIL TRADISIONAL DAN UKM
}

\author{
Hasanuddin ${ }^{1)}$, Aryanto ${ }^{2)}$ \\ ${ }^{1,2)}$ Fakultas Ilmu Komputer Universitas Muhammadiyah Riau \\ Jl. KH Ahmad Dahlan No. 88 Pekanbaru Riau \\ e-mail: hasan@umri.ac.id ${ }^{1)}$, aryanto@umri.ac.id $^{2)}$
}

\begin{abstract}
ABSTRAK
Kegiatan usaha masyarakat tradisional khususnya di kalangan menengah ke bawah masih memiliki banyak permasalahan. Kebutuhan terhadap modal usaha, jaringan penyuplai barang hingga kegiatan pemasaran merupakan hal utama yang dirasakan oleh mereka. Di sisi lain perkembangan teknologi informasi dan komunikasi telah berkembang pesat dan belum diterapkan secara maksimal di lingkungan masyarakat menengah ke bawah khususnya bagi para pelaku usaha retail tradisional dan Usaha Kecil Menengah (UKM). mereka masih kesulitan dalam hal akses maupun penggunaan teknologi tersebut. Permasalahan lain yang terkait adalah jumlah konsumen yang cendrung fluktuatif dan cendrung menurun karena menjamurnya bisnis-bisnis retail modern dengan jaringan yang luas dan kuat. Dalam penelitian ini akan dibangun suatu aplikasi electronic Customer Relationship Management (e-CRM) yang dapat dijadikan pendukung kegiatan usaha sehingga dapat meningkatkan penjualan, memperluas pangsa pasar dan meningkatkan jumlah pelanggan bagi para pelaku usaha retail tradisional dan UKM. Tahapan penelitian yang dilakukan adalah analisis kebutuhan sistem, perancangan sistem, pembuatan aplikasi dan pengujian sistem.Diharapkan dengan penerapan aplikasi ini, para pelaku usaha retail tradisional dan UKM dapat lebih bersemangat dan menambah motivasi untuk bersaing dalam bisnis retail di era globalisasi ini. Aplikasi ini akan diterapkan berbasis web dan mobile android sehingga para pelanggan dapat melakukan pemesanan secara online dengan cepat dan mudah.
\end{abstract}

Kata Kunci: e-CRM, UKM, retail tradisional, teknologi informasi, globalisasi.

\begin{abstract}
Traditional community business activities, especially in the lower middle class, still have many problems. The need for business capital, the supply network of goods to marketing activities is the main thing that is felt by them. On the other hand, the development of information and communication technology has developed rapidly and has not been fully implemented in the lower middle class environment, especially for traditional retailers and Small and Medium Enterprises (SMEs). they are still having difficulties in accessing and using the technology. Another related problem is the number of consumers who tend to fluctuate and tend to decline due to the proliferation of modern retail businesses with a broad and strong network. In this study, an electronic application of Customer Relationship Management (e-CRM) that can be used as a support for business activities will be built so as to increase sales, expand market share and increase the number of customers for traditional retailers and SMEs. The stages of research carried out are system requirements analysis, system design, application creation and system testing. It is expected that with the application of this application, traditional retail business actors and SMEs can be more enthusiastic and increase motivation to compete in the retail business in this globalization era. This application will be applied based on web and mobile android so that customers can place orders online quickly and easily.
\end{abstract}

Keyword : e-CRM, UKM, retail tradisional, teknologi informasi, globalisasi 


\section{Hasanuddin, Aryanto}

Jurnal Fasilkom Vol. 8 Nomor 1 (2019) 299-302

\subsection{Pendahuluan}

Perkembangan bisnis ritel di Indonesia dapat dikatakan cukup pesat akhir-akhir ini, terutama ritel modern dalam semua variasi jenisnya. Beberapa faktor pendukung perkembangan usaha ritel modern diantaranya adalah cukup terbukanya peluang pasar, perkembangan usaha manufaktur yang akan memasok produknya ke retailer (peritel), dan upaya pemerintah untuk mendorong pertumbuhan ekonomi dengan cara salah satunya mengembangkan bisnis ritel.

Vanessa Gaffar F., CRM dan MPR Hotel (Customer Relationship Management and Marketing Public Relation), Penerbit Alfabeta, Jakarta, 2007, hal. 98-101.

Teknologi informasi merupakan salah satu faktor pendukung meningkatnya produktivitas proses bisnis dari suatu organisasi pada era globalisasi yang semakin berkembang pesat. Penerapan teknologi informasi tentunya harus diimbangi dengan pengelolaan yang memadai. Sama halnya dengan penyedia layanan pendidikan yang memerlukan informasi sebagai pondasi keberhasilan kinerjanya. Salah satu penerapan teknologi informasi dalam bidang akademik adalah sistem informasi akademik.

Perkembangan yang dialami bisnis ritel, dalam perjalanannya bukannya tanpa menimbulkan masalah sama sekali. Banyaknya pemain dalam bisnis ritel membuat persaingan menjadi sangat ketat. Peritel besar, semakin gencar melakukan ekspansi bisnisnya sementara peritel kecil dan tradisional menjadi pihak yang berada dalam kondisi yang tidak menguntungkan.

Pengamatan para pakar dan peneliti bisnis ritel umumnya sampai pada kesimpulan bahwa kehadiran peritel besar dalam bentuk hipermarket, supermarket, department store, dan lain-lain, membahayakan kelangsungan hidup bisnis ritel kecil dan tradisional. Peneliti ritel Fakultas Ekonomi Universitas Indonesia (FE UI) Rizal Halim (Bisnis.Com, 23/8/2009), dalam sebuah pengamatannya terhadap kehadiran hipermarket menyatakan bahwa, dari kehadiran hipermarket terdapat dua kemungkinan yang ditimbulkan yaitu toko lokal atau warung yang tutup atau peritel skala kecil mengurangi karyawannya karena omzetnya berkurang.
Persaingan dalam bisnis ritel bahkan meluas dengan keterlibatan para pemasok (supplier). Sebuah peristiwa yang muncul menjadi berita, pemasok meminta pemerintah segera mengawasi penerapan Permendag No. 53/ 2008 tentang Pedoman Penataan dan Pembinaan Pasar Tradisional. Sebab, masih ada pengecer (peritel) yang mematok potongan harga tetap (fixed rebate) sebesar 8\% dari ketentuan maksimal 1\% (Kontan, 16 Januari 2009).

\section{METODE PENELITIAN}

Penelitian ini dilaksanakan dalam bentuk pembuatan aplikasi perangkat lunak berbasis web dan mobile android. Tahapan-tahapan yang akan dilaksanakan dalam penelitian ini adalah sebagai berikut:

\section{Analisis dan pengumpulan data}

Merupakan langkah awal dalam hal menentukan analisis kebutuhan sistem. Analisis ini dilakukan untuk memastikan bahwa sistem yang akan dikembangkan sesuai dengan kebutuhan pengguna. Analisis ini terdiri dari analisis kebutuhan fungsional dan kebutuhan non-fungsional. Untuk mendukung analisis yang tepat dan akurat, tahapan analisis ini didahului dengan pengumpulan data.

\section{Desain}

Pada tahapan desain (perancangan) sistem, dilakukan perancangan beberapa komponen sistem antara lain : perancangan data, perancangan interface (antar muka). Perancangan tersebut diharapkan memudahkan pembuat sistem dalam menerjemahkan kebutuhan pengguna dalam bentuk visual. Dalam pembuatan desain ini dipertimbangkan aspek user-friendly untuk kemudahan penggunaan, sehingga pengguna yang kemampuan teknis pemula sekalipun dapat menggunakan sistem ini dengan baik dan benar.

\section{Implementasi}

Hasil perancangan pada tahapan desain, selanjutnya diimplentasikan melalui teknologi berbasis web dan mobile android. Pada tahapan implementasi ini akan digunakan web framework open-source yang akan ditempatkan pada suatu server. Pada bagian akhir dari implementasi ini adalah pemasangan sistem 


\section{Hasanuddin, Aryanto}

Jurnal Fasilkom Vol. 8 Nomor 1 (2019) 299-302

pada server web dan pengaturan beberapa hal untuk keamanan sistem. Pada langkah ini, sistem akan dipasang pada server berbasis sistem operasi LINUX dengan server tersendiri pada suatu perusahaan ISP (Internet Service Provider) ternama dan berpengalaman.

\section{Evaluasi dan Ujicoba sistem}

Merupakan langkah untuk memastikan bahwa sistem yang telah dikembangkan dan dipasang telah berjalan dengan baik sesuai analisa kebutuhan yang telah ditentukan. Pengujian dan evaluasi ini akan dilaksanakan dalam dua kelompok kegiatan, pertama pengujian internal oleh pengembang. Sedangkan kegiatan kedua adalah pengujian terbuka oleh beberapa perwakilan pelaku bisnis retail tradisional dan UKM di kecamatan Tampan kota Pekanbaru.

\section{HASIL DAN PEMBAHASAN}

Pada penelitian ini dihasilkan aplikasi dalam bentuk aplikasi berbasis web dan android berupa layanan-layanan sebagai berikut :

\section{Halaman input UKM/usaha retail}

Merupakan halaman untuk mendata UKM/usaha retail di Kota Pekanbaru. Melalui layanan ini diharapkan sebagai validasi UKM/usaha retail yang sah dan diberi kesempatan untuk memasarkan produknya melalui sistem ini. Hal ini dimaksudkan agar meminimalkan keraguan dan ketidakpercayaan publik terhadap faktor penipuan atau penyalahgunaan nama UKM/usaha retail.

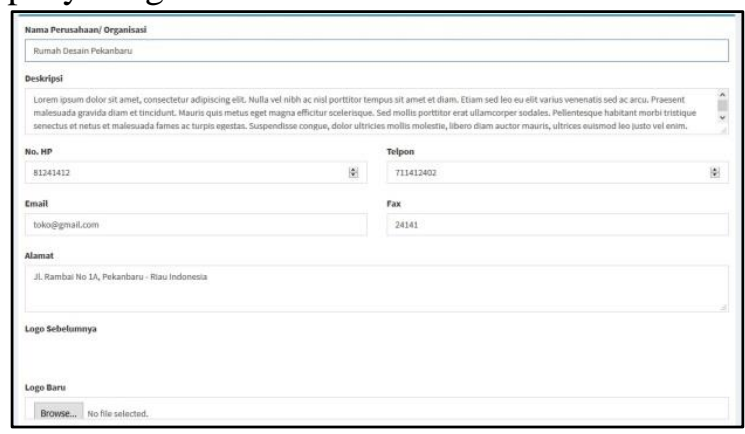

Gambar 1. Halaman input UKM/usaha retail

\section{Halaman input berita/informasi}

Merupakan layanan untuk memasukkan berita atau informasi seputar pemasaran produk misal informasi potongan harga khusus, informasi produk baru, dan lain sebagainya.

\section{Halaman input produk}

Merupakan layanan untuk mendata produkproduk/barang yang dihasilkan oleh UKM atau yang dipromosikan oleh usaha retail tradisional. Halaman ini diberikan pada sisi pengelola UKM/usaha retail untuk memasukkan data.

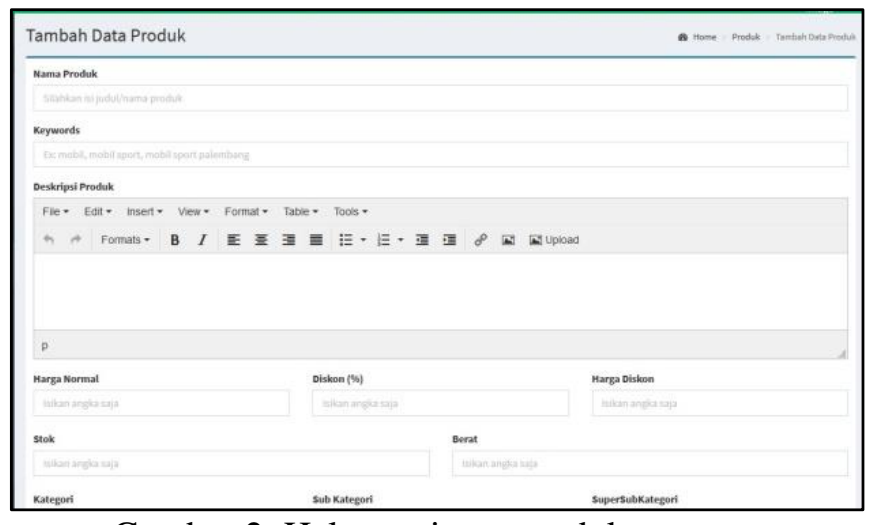

Gambar 2. Halaman input produk

4. Halaman input jenis produk/barang Merupakan layanan untuk memasukkan dan mengelola kategori atau jenis produk/barang. Jenis produk ini dimaksudkan untuk mengelompokkan produk-produk/barang yang diinputkan oleh pengelola UKM/usaha retail sehingga memudahkan penyajian data dan pencarian oleh pembeli/pelanggan.

\section{Halaman input data pelanggan}

Merupakan layanan untuk memasukkan data pembeli atau pelanggan yang melakukan transaksi pemesanan produk. Halaman ini dapat diakses langsung oleh pengunjung. Layanan ini digunakan sebagai validasi terhadap transaksi pembelian atau pemesanan produk/barang.

\section{Halaman pencarian produk}

Merupakan layanan bagi pengnjung atau calon pelanggan untuk mencari produk/barang yang sesuai dengan keinginan mereka. Hal ini disebabkan dalam sistem ini nantinya akan terdapat berbagai jenis barang dan variasi UKM/usaha retail sehingga data produk yang tersaji merupakan data dalam jumlah yang besar. Untuk itu diperlukan solusi untuk memberikan kemudahan bagi pembeli dalam mencari barang yang tepat. 


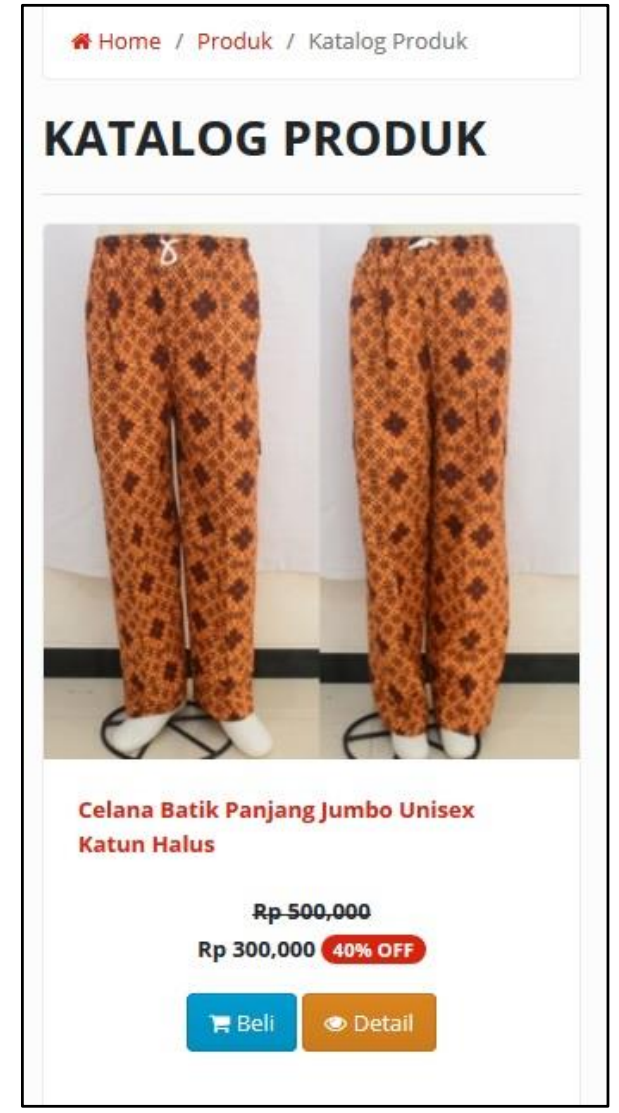

Gambar 3. Halaman pencarian produk

7. Halaman pemesanan Produk

Merupakan halaman untuk pemesanan produk oleh pembeli/pelanggan. Dalam pemesanan produk ini dibutuhkan data pembeli, data produk serta kuantitas yang akan dipesan/dibeli. Hasil transaksi ini selenjutnya tersimpan pada sistem untuk selajutnya dapat diproses melalui layanan konfirmasi pembayaran dan pengisian status pengiriman barang/produk

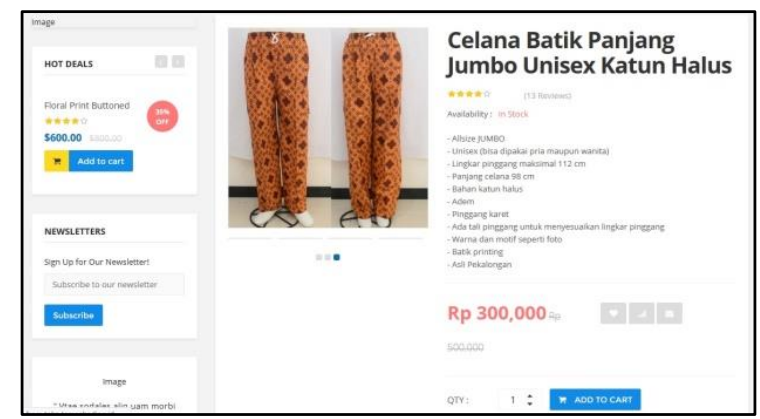

Gambar 4. Halaman pemesanan produk

\section{PENUTUP}

Kesimpulan dalam penelitian ini adalah telah dapat dibangun prototipe aplikasi berbasis web dan android dalam hal penerapan e-CRM pada jaringan usaha ritel/UMKM di kota Pekanbaru. Ucapan terima kasih kami sampaikan sebesarbesarnya bagi Kementrian Ristekdikti dan Kopertis Wilayah X yang telah mendanai dan mensupport pelaksanaan penelitian ini secara maksimal.

\section{DAFTAR PUSTAKA}

[1] Budi Winarno, Kebijakan Publik Era Globalisasi: Teori, Proses, dan Studi Kasus Komparatif, Penerbit Caps, Jakarta, 2016, hal. 15-20.

[2] Jubilee Enterprise, Customer Relationship Management (CRM) dengan Blog, Elex Media Komputindo, Jakarta, 2009, hal. 7590.

[3] Mukti Fajar, UMKM di Indonesia: Perspektif Hukum Ekonomi, Pustaka Pelajar, Jakarta, 2016, hal. 110-112.

[4] Parlagutan Silitonga, Manajemen UMKM dan Sumber Daya Manusia, Andi Offset, Yogyakarta, 2017, hal. 60-62.

[5] Rachma Fitriati, Menguak Daya Saing UMKM Industri Kreatif: Sebuah Riset Tindakan Berbasis Soft Systems Methodology, Yayasan Obor Indonesia, Jakarta, 2015, hal. 95-98.

[6] Tulus T.H. Tambunan, UMKM di Indonesia, Ghalia Indonesia, Jakarta, 2009, hal. 120-122. 